\title{
PENGARUH EKSTRAK KULIT BUAH MANGGIS (GARCINIA MANGOSTANA L.) TERHADAP HISTOLOGIS PANKREAS MENCIT (MUS MUSCULUS L. SWISS WEBSTER) YANG DIINDUKSI SUKROSA
}

\author{
Khairani, Elsa Yuniarti, Ramadhan Sumarmin \\ Program Studi Biologi, FMIPA, Universitas Negeri Padang \\ e-mail : raniranott.94@gmail.com \\ DOI : 10.24036/eksakta/vol19-iss01/123
}

\begin{abstract}
Diabetes Mellitus (DM) is a metabolic disorder caused by lack of insulin which islet cells of Langerhans in the pancreas were damaged or decreased. DM treatment is quite expensive so it takes the alternative medicine. Ones of alternative medicine using Mangosteen Fruit pod. The pod of the mangosteen fruit have xanton flavonoid compounds, which function as antioxidants that can lower blood glucose levels and improve pancreatic cells. The study aimed to determine the effect of mangosteen rind extract (Garcinia mangostana L.) to display the pancreatic histology of mice (Mus musculus L. Swiss Webster) induced male sucrose. This study used Completely Randomized Design (CRD) with 5 treatments and 5 replications. treatments is P1 (positive control), sucrose $0.8 \mathrm{~g} / \mathrm{kg}$ (negative control / P2), sucrose $+200 \mathrm{mg} / \mathrm{kg}$ of mangosteen peel extract (P3), sucrose $+400 \mathrm{~g} / \mathrm{kg}$ of mangosteen peel extract ( P4), sucrose $+600 \mathrm{mg} / \mathrm{kg}$ of mangosteen peel extract (P5). Observations quantitatively to determine blood glucose levels and the number of Langerhans islet cells after 5 days and 4 days inducing the extract. Data were analyzed by ANOVA, if there is a difference will be continued with Duncan test at the 0.05 significance level. The results showed the average number of Langerhans islet cells 205.6 (P1), 134.0 cells (P2), 114.2 cells (P3), 193.0 cell (P4), and 181.8 cells (P5). From the results obtained in the analysis of data obtained Fhitung<Ftabel significant at 0.05, so it can be concluded that the mangosteen rind extract has no effect on pancreatic histological induced male mice sucrose.
\end{abstract}

Keywords : Diabetes Mellitus (DM), blood glucose, pancreas, islet cells langerhasn, mangosteen (Garcinia mangostana)

\section{PENDAHULUAN}

Dewasa ini, berbagai macam penyakit diderita oleh masyarakat dunia khususnya Indonesia, salah satunya Diabetes Mellitus (DM) (Nugrahani, 2012). World Health Organization (WHO) menjelaskan lebih dari 220 juta orang diseluruh dunia mengidap diabetes. Pada tahun 2004, 3,4 juta orang meninggal karena penyakit ini (Soegondo dkk, 2009). International Diabetes Federation atau IDF (2014) menyatakan bahwa penderita diabetes mellitus di dunia pada tahun 2014 mencapai 387 juta orang dan diperkirakan pada tahun 2035 mencapai 592 juta orang. World Health Organization (WHO) memprediksi kenaikan jumlah penyandang DM di 
Indonesia dari 8,4 juta pada tahun 2000 menjadi sekitar 21,3 juta pada tahun 2030 (Soegondo dkk, 2009).

Diabetes mellitus adalah suatu jenis penyakit kelainan metabolisme yang disebabkan kurangnya hormon insulin. Kekurangan hormon insulin mengakibatkan glukosa yang dikonsumsi tidak dapat diproses oleh tubuh secara sempurna. Hal ini menyebabkan kadar glukosa darah meningkat (Utami dan Tim lentera, 2004). Glukosa darah akan terus meningkat setelah makan makanan dengan sumber karbohidrat, namun sekitar 2 jam setelah itu glukosa akan turun dan kembali dalam keadaan normal (Poedjadi, 2006).

Apabila glukosa darah tinggi,
maka kelenjar pankreas akan mengeluarkan insulin dan masuk ke dalam aliran darah. Jika kadar insulin cukup atau fungsinya tidak terganggu, kelebihan glukosa darah akan disimpan atau digunakan untuk metabolisme (Utami dan Tim lentera, 2004). Insulin berperan penting dalam metabolisme karbohidrat, lemak dan protein serta dalam transport berbagai zat melalui membran sel (Ganiswarna, 1995). Insulin merupakan suatu hormon yang diproduksi oleh sel pankreas. Sel-sel pankreas yang mensekresikan insulin adalah sel beta pulau Langerhans (Pearce, 2002).

Pada penderita penyakit DM, selsel Langerhans mengalami kerusakan sehingga sekresi insulin berkurang, sel beta berdegranulasi dan sitoplasma kosong (Dayatri, 2009). Turunnya insulin akan mengakibatkan hiperglikemia (Ganong, 1995). Pengobatan penyakit DM cukup mahal, sehingga dibutuhkan alternatif obat yang murah, mudah didapat, dan tidak memberikan efek samping yang berarti. Sehingga mulai dikembangkan pengobatan alternatif menggunakan tanaman herbal sebagai obat (Yatman, 2012).

Salah satu tanaman yang banyak digunakan sebagai obat adalah Manggis
(Garcinia mangostana L.) (Fransiska dkk, 2014). Tanaman manggis memiliki banyak manfaat. Kulit buah manggis pun sangat kaya akan zat-zat bermanfaat bagi tubuh (Pebriyanti dan Erlina, 2010). Kulit buah manggis terbukti mengandung antioksidan yang sangat tinggi yakni senyawa yang dapat bereaksi dengan radikal bebas sehingga mengurangi kapasitas radikal bebas dimana radikal bebas penyebab timbulnya kerusakan pada sel, jaringan dan atau organ (Indrajati, 2013). Kandungan antioksidan ekstrak kulit manggis juga berperan penting pada penurunan kadar glukosa darah (Darmawangsyih, 2014). Antioksidan dapat mengikat radikal hidroksil yang merusak sel $\beta$ pulau Langerhans Pankreas. Sehingga produksi insulin akan maksimal (Dewi dkk, 2014).

Kulit buah manggis mengandung senyawa golongan alkaloid, triterpenoid, saponin, flavonoid, tannin dan polifenol (Dewi dkk, 2013). Kandungan kimia kulit buah manggis adalah xanton, mangostin, garsion, flavonoid, tannin dan senyawa lainnya (Emilan dan Ashfar, 2011). Metabolit sekunder dari kulit buah manggis adalah xanton (Dewi dkk, 2013).

Xanton merupakan substansi kimia alami yang tergolong senyawa polifenolik dan memiliki hubungan dekat dengan senyawa flavonoid (Yatman, 2012). Flavonoid merupakan senyawa fenolik alam yang memiliki potensi sebagai antioksidan dan biokaktifasi sebagai obat (Rohyami, 2008). Astuti (2012) menjelaskan flavonoid berfungsi dalam menghambat enzim glukosidase dan alfa amylase sehingga pemecahan karbohidrat menjadi gagal dan glukosa tidak dapat diserap oleh usus. Senyawa xanton yang terkandung dalam kulit buah manggis memiliki antioksidan yang tinggi serta bersifat sebagai imunomodulator yang dapat menstabilkan sel-sel di dalam tubuh (Mardiana, 2011). Handayani (2013) menyatakan Imunomodulator merupakan senyawa yang dapat 
mengembalikan, memperbaiki dan mempetahankan sistem imun yang fungsinya terganggu atau menekan yang fungsinya berlebihan.

\section{METODE PENELITIAN}

\section{A. Waktu dan Tempat}

Penelitan dilaksanakan dari Desember 2015 sampai Februari 2016 di Laboratorium Zoologi dan Divisi Hewan Jurusan Biologi FMIPA Universitas Negeri Padang.

\section{B. Alat dan Bahan}

Alat yang digunakan dalam penelitian adalah: pisau, lumpang dan alu, Erlenmeyer, timbangan digital, water bath, desikator, botol plastik, cawan petri, alat tulis, kertas label, botol minum mencit, batang pengaduk, gelas ukur, hotplate magnetic stirrer, baskom plastik, Bunsen, kawat, corong, neraca Ohaus, jarum Gavage, Gluko Dr, kuas, $K$ Sentrifuge plc series, Shaker, pompa vakum, suntik, tabung reaksi, disetting set, kaca objek, gelas penutup, mikroskop, tissue box, inkubator, blok holder, pisau mikotom, mikotom, tuas pengatur dan kotak preparat.

Bahan yang dibutuhkan adalah mencit (Mus musculus L.,) Swiss Webster jantan berumur 8-10 minggu dengan berat badan 25-30 gr, kulit buah manggis (Garcinia mangostana L.), strip gula darah, eosin, ketaman kayu, aluminium foil, korek api, kapas, tissue, makanan mencit, methanol, NA-CMC 2\%, larutan Bouin, alkohol (70\%, 80\%, 90\%, 95\%, absolute I, II, dan III), xylol (I,II dan III), pewarna HE (Hematoksilin-Eosin), air ledeng dan aquades.

\section{Rancangan Penelitian}

Penelitian ini adalah penelitian eksperimen menggunakan Rancangan Acak Lengkap (RAL) dengan 5 perlakuan dan 5 ulangan. Adapun dosis perlakuan dan dosis sukrosa yang diberikan adalah sebagai berikut:

P1. Kontrol positif tanpa perlakuan
E-ISSN : 2549-7464, P-ISSN : 1411-3724

P2. Kontrol negatif sukrosa $0,8 \mathrm{~g} / \mathrm{Kg} \mathrm{BB}$

P3. Sukrosa + Ekstrak kulit buah manggis $200 \mathrm{mg} / \mathrm{Kg}$ b.b.

P4. Sukrosa + Ekstrak kulit buah manggis $400 \mathrm{mg} / \mathrm{Kg}$ b.b.

P5. Sukrosa + Ekstrak kulit buah manggis $600 \mathrm{mg} / \mathrm{Kg}$ b.b.

Pemberian dosis perlakuan didapatkan berdasarkan dari dosis (Garcinia mangostana L.) yang telah dikonversikan dosis untuk mencit (Mus musculus L.).

\section{Prosedur Penelitian}

1. Persiapan Penelitian

a. Persiapan Hewan Uji

Hewan uji yang digunakan adalah mencit (Mus musculus L.,) Swiss Webster jantan yang diperoleh dari Laboraturium Zoologi Jurusan Biologi FMIPA Universitas Negeri Padang.

Mencit yang diambil sebagai hewan uji adalah mencit jantan berumur 8-10 minggu dengan berat 25-30 gr. Mencit ditandai dan ditimbang terlebih dahulu berat awal dan pada akhir penelitian, mencit ditimbang kembali untuk mendapatkan berat akhir.

b. Persiapan Media

Mencit jantan ditempatkan pada kandang yaitu baskom plastik bentuk segi empat ukuran $30 \mathrm{~cm}$ (p) x $20 \mathrm{~cm}$ (l) x 10 $\mathrm{cm}(\mathrm{t})$ yang disekat agar mencit tidak berkelahi dan ditutup dengan kawat. Kandang diberi tanda sesuai dosis perlakuan. Kandang dialasi dengan sekam dan diganti setiap 1 x 2 hari. Mencit diberi tanda menggunakan eosin dibagian ekstremitas. Selama pemeliharan, mencit diberi pakan pelet sebanyak 8-10 butir 2 kali sehari dan air minum.

c. Pembuatan Ekstrak Kulit Buah Manggis (Garcinia mangostana L.)

Ekstrak kulit buah manggis dibuat dengan cara mengambil $250 \mathrm{~g}$ kulit buah manggis yang sudah dikering anginkan selama 10 hari, tujuannya karena kulit buah manggis yang sudah dikeringkan lebih tahan lama penyimpanan daripada 
kulit buah manggis yang masih basah dan bisa digunakan dalam jangka waktu yang lama. Kulit buah manggis yang sudah kering kemudian digiling dan dijadikan simplisia. Simplisia tersebut direndam dalam methanol sebanyak $500 \mathrm{ml}$ selama 48-72 jam. Selanjutnya, difiltrasi dengan menggunakan pompa vakum untuk memisahkan serbuk kulit buah manggis, filtrasi yang didapat dipekatkan melalui rotasi vakumevaporatus (rovapor) dan evaporasi dengan waterbath lalu dikeringkan menggunkan inkubator agar stabil. Ekstrak kulit buah manggis yang didapat berupa lempengan padat, diserbukkan dengan cara ditumbuk dalam lempengan porselen dan ditimbang sesuai dosis perlakuan. Untuk pemberian pada hewan percobaan ekstrak diemulsikan dan diencerkan dengan larutan Na-CMC $2 \%$.

d. Pembuatan Larutan Na-CMC 2\%

Bubuk Na-CMC ditimbang sebanyak 0,2 g kemudian dilarutkan dalam larutan aquades hingga volume mencapai $100 \mathrm{ml}$ dan diaduk hingga homogen dengan batang pengaduk. Campuran tersebut disimpan dalam botol tertutup diberikan label $\mathrm{Na}-\mathrm{CMC} 2 \%$ digunakan sebagai pelarut ekstrak yang akan digunakan.

e. Penentuan Dosis dan Lama Pemberian

Ekstrak

Dosis yang diberikan sebanyak 200 $\mathrm{mg} / \mathrm{Kg}$ BB; $400 \mathrm{mg} / \mathrm{Kg}$ BB dan 600 $\mathrm{mg} / \mathrm{Kg}$ BB. Pemberian ekstrak pada hewan uji berlangsung selama 4 hari. Pemberian ekstrak kulit buah manggis dilakukan secara oral dengan menggunakan syiringe tuberculin $1 \mathrm{ml}$ yang dimodifikasi dan dilengkapi jarum Gavage.

f. Pembuatan Larutan Sukrosa

Dosis sukrosa dihitung berdasarkan dosis sukrosa pada tikus yaitu $5,625 \mathrm{~g} / \mathrm{kg}$ $\mathrm{BB}$, maka perhitungan dosis sukrosa untuk mencit adalah 5,625:7,00 =0,8 $\mathrm{g} / \mathrm{kg} \quad \mathrm{BB} \quad(7,00)$ merupakan faktor konveksi dosis tikus ke mencit). Dosis sukrosa yang akan digunakan, dihitung berdasarkan berat badan masing-masing hewan uji, kemudian dilarutkan dalam aquades sebanyak $0,5 \mathrm{ml}$ dan diberikan kepada hewan uji.

\section{Pelaksanaan Penelitian}

a. Pemberian Sukrosa

Terlebih dahulu mencit (Mus musculus

L.) Swiss Webster jantan dipuasakan selama 12 jam dari jam 19:00 sampai jam 07:00 WIB tetapi tetap diberi minum. Dilakukan pengamatan kadar glukosa darah basal setelah 12 jam dipuasakan. Setelah itu, sebelum pemberian sukrosa, mencit ditimbang terlebih dahulu, untuk mendapatkan berat awal. Larutan sukrosa diambil sebanyak $0,8 \mathrm{~g} / 1000 \mathrm{~g}$ BB sesuai berat mencit dan dilarutkan dalam aquades sebanyak 0,5 ml. Larutan dicekokkan ke mencit. Pemberian larutan diberikan selama 5 hari induksi. Kadar darah diukur setelah 5 hari penginduksian.

b. Pemberian Ekstrak Kulit Buah Manggis

Ekstrak kulit buah manggis diberikan dengan dosis tunggal sesuai perlakuan selama 4 hari dengan cara mencekokkan ekstrak sesuai perlakuan. Pada hari pertama dan terakhir pencekkok, berat badan mencit ditimbang. Pemeriksaan glukosa darah pada hari ke 4 setelah 3 jam pemberian perlakuan sebagai berikut :

1) Botol plastik dibersihkan terlebih dahulu yang telah dibuka tutupnya dengan memotong bagian bawah botol

2) Mencit dimasukkan kedalam botol plastik dengan mengarahkan kepalanya ke bagian kepala botol yang telah dibuka tutupnya, sempitkan bagian bawah botol, sehingga hanya ekor yang keluar dari botol bertujuan untuk memudahkan pengambilan darah

3) Ekor mencit yang sudah dipotong ujungnya. Sebelum dilukai ekor mencit dioleskan alkohol $70 \%$ agar daerah tersebutsteril

4) Ekor mencit yang dipotong diolesi dengan kapas yang sudah diberi xylol agar darah berhenti keluar 
5) Darah yang keluar diteteskan pada strip Glukos $\mathrm{Dr}$ yang telah dipasangkan pada Gluko Dr

6) Alat ini membutuhkan waktu 10 detik dalam penentuan berapa nilai glukosa mencit. Tahap selanjutnya dicatat data hasil pengukuran.

\section{Pembuatan Preparat Histologis} Pankreas

a. Pengambilan Jaringan

Pengambilan jaringan adalah awal sebelum dilanjutan ke prosedur pembuatan preparat. Hewan yang akan diambil jaringannya terlebih dahulu dibunuh dengan klorofom. Dilakukan pembedahan selanjutya mengambil jaringan dan dibersihkan dengan larutan fisiologis.

b. Fiksasi (Pengawetan Jaringan)

Sampel diletakkan dalam botol sampel yang telah diberi label dengan jelas dan digunakan Bouin sebagi fiksasi untuk potongan jaringan pankreas. Tujuan untuk mengawetkan jaringan untuk sementara, dan mencegah terjadinya kerusakan struktur serta komponen aktif jaringan.

c. Dehidrasi (Penarikan Air)

Digunakan alkohol 70\%, 80\%, 90\%, dan 95\%, alcohol absolut I, II, dan III dengan cara merendamkan jaringan sampel yang telah tersimpan dalam "tissue box". Waktu yang diperlukan:

$$
\text { Alkohol 70\% }
$$

hari

hari Alkohol 80\%

hari

Alkohol 95\%

hari

Alkohol Ansolut I $\quad 1$

jam

Alkohol Absolut II 1

jam

Alkohol Absolut III

jam

1

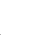

1

d. Clearing (Penjernian)

Setelah sampel jaringan pankreas didehidrasi makan dilakukan clearing atau penjernihan. Tujuannya adalah untuk menghilangkan atau mengeliminir sisasisa bahan yang mungkin akan dapat mengganggu proses infiltrasi atau pewarnaan. Larutan yang digunakan Xylol I, II dan III dengan waktu 1 jam untuk xylol I dan II sedangkan xylol III selama 30 menit dengan suhu ruang, setelah itu diinkubasi selama 30 menit. Pada xylol III sampel jaringan sudah dikeluarkan dari "tissue box".

e. Embedding (Penanaman Jaringan dalam Parafin)

Sebelum embedding jaringan yang berada dalam xylol III telah diletakkan dalm inkubator dengan suhu sesuai suhu parafin yang digunakan untuk embedding. Jaringan pankreas tersebut harus dinfiltrasi dengan parafin yang tadinya terisi oleh xylol diganti oleh parafin.

\section{f. Sectioning (Penyayatan atau Pemotongan)}

Blok parafin yang telah didinginkan di dalam lemari es kemudian diambil dan dipasangkan pada penjepit blok holder mikrotom. Kemudian diatur dan diarahkan kesejajaran permukaan dengan cara mengatur tuas pengatur yang ada pada blok holder mikrotom hingga didapatkan keserasian posisi pemotongan dengan ketebalan pemotongan adalah $4 \mu$. Potongan yang baik dan terpilih kemudian dikeringkan daiats hotplate $\left(38-40^{\circ} \mathrm{C}\right)$ selama 24 jam atau lebih untuk penyempurnan penempelan jaringan pada gelas objek dan selajutnya siap untuk diwarnain. Penempelan di gelas objek menggunakan putih telur yang dikenal dengan "Mayer's Albumen".

g. Staining (Perwarnaan)

Preparat yang telah menempel pada gelas objek dengan baik kemudian dipilih dan diberi label baru dan disesuaikan dengan pewarnaannya. Sedian pankreas diwarnai dengan pewarna HematoksilinEosin. Preparat atau sedian seri yang dipilih disusun dalam rak preparat. 
Kemudian dilakukan deparafinitas sebagai berikut:

Deparafinitas

Xylol I
menit Xylol II
3 menit
Xylol III
3 menit
Rehidrasi

$\begin{array}{lll} & \text { Alkohol Absolut I } & 3 \\ \text { menit } & \text { Alkohol Absolut II } & 3 \\ \text { menit } & \text { Alkohol Absolut III } & 3 \\ \text { menit } & & \end{array}$

menit

Alkohol 70\%

3

$$
\text { Alkohol 80\% }
$$

menit

Alkohol 90\%

menit

Alkohol 95\%

menit

Air Ledeng

menit

Akuades

menit

Pewarnaan Hematoksilin

5 menit

Air Ledeng

menit

Akuades

menit

Pengamatan Mikroskop

Pewarnaan Eosin

2-3 menit

Dehidrasi

Alkohol 70\%

beberapa detik

Alkohol 80\%

beberapa detik

Alkohol 90\%

beberapa detik

Alkohol Ansolut I

beberapa detik

Alkohol Absolut II
E-ISSN : 2549-7464, P-ISSN : 1411-3724

Alkohol Absolut III

3

menit

Xylol I

3 menit

Xylol II

3 menit

Xylol III

3

menit

Pengamatan menggunakan Digital Photomicroskop dengan perbesaran terkecil sampai terbesar. Pengambilan gambaran histologi menggunakan kamera. Kriteria pengamatan berupa jumlah sel pada pulau Langerhans pankreas (Sholikhatindkk, 2013).

\section{E. Teknik Analisis Data}

Analisis data yang digunakan dalam penelitian ini berupa data kuantitatif untuk mengetahui kadar glukosa darah dan jumlah sel pulau langerhans dianalisis menggunakan uji Anlysis of Variant (ANOVA). Didapatkan $F_{\text {hitung }}>F_{\text {tabel }}$ maka dilanjutkan dengan uji lanjut Duncan 5-10 dengan perbedaan signifikan 0,05 (Pollet, 1994).

menit

\section{HASIL DAN PEMBAHASAN}

\section{A. Hasil Penelitian}

Berdasarkan hasil pengamatan kadar glukosa mencit (Mus musculus L.) jantan yang diinduksi sukrosa selama 5 hari didapatkan hasil rata-rata yang bervariasi pada masing-masing mencit jantan. Pada pengamatan glukosa darah mencit jantan yang diberikan ekstrak kulit buah manggis (Garcinia mangostana) selama 4 hari juga didapatkan hasil rata-rata glukosa darah mencit jantan yang bervariasi dan mengalami penurunan terhadap kadar glukosa darah mencit yang diambil pada hari ke 4 setelah 3 jam pemberian ekstrak kulit buah manggis.

Tabel 1. Rata-rata Kadar Glukosa Darah Mencit

(Mus musculus L.) Jantan yang Diberikan Perlakuan. 


\begin{tabular}{|c|c|c|}
\hline \multirow{2}{*}{ Perlakuan } & \multicolumn{2}{|c|}{$\begin{array}{c}\text { Rata-rata Kadar Glukosa } \\
\text { Darah }\end{array}$} \\
\cline { 2 - 3 } & $\begin{array}{c}\text { Data } \\
\text { setelah } \\
\text { Induksi } \\
\text { Sukrosa } \\
\text { Hari ke-6 } \\
\text { (mg/dL) }\end{array}$ & $\begin{array}{c}\text { Data setelah } \\
\text { Pemberian } \\
\text { Ekstrak } \\
\text { Kulit Buah } \\
\text { Manggis } \\
\text { Hari ke-9 } \\
(\mathrm{mg} / \mathrm{dL})\end{array}$ \\
\hline P1 & 86,0 & $64,4^{\mathrm{a}}$ \\
\hline P2 & 101,4 & $81,6^{\text {ab }}$ \\
\hline P3 & 89,0 & $75,0^{\text {abc }}$ \\
\hline P4 & 91,6 & $41,2^{\text {bc }}$ \\
\hline P5 & 83,8 & $51,2^{\mathrm{c}}$ \\
\hline
\end{tabular}

Keterangan: Pada kolom yang sama angka yang diikuti huruf superscript berbeda, berbeda nyata pada $\mathrm{p}<0,05$ pada uji Duncan.

Berdasarkan Tabel 1 setelah dianalisis dengan menggunakan uji ANOVA di peroleh data yaitu, pada hari ke-6 dimana $\mathrm{F}$ hitung $<\mathrm{F}$ tabel pada taraf 5\%. F hitung sebesar 0,36, sedangkan $F$ tabel 2,9 pada taraf $5 \%$ sehingga tidak dilakukan uji lanjut. Pada hari ke-9 F hitung > F tabel. F hitung sebesar 3,37 pada taraf 5\% sedangakan $\mathrm{F}$ tabel sebesar 2,9 pada taraf 5\% sehingga dilakukan uji lanjut Duncan.

Tampilan histologis pankreas mencit jantan yaitu sel-sel pulau Langerhans dapat dilihat pada Gambar 7, sebagai berikut:

\section{E-ISSN : 2549-7464, P-ISSN : 1411-3724}

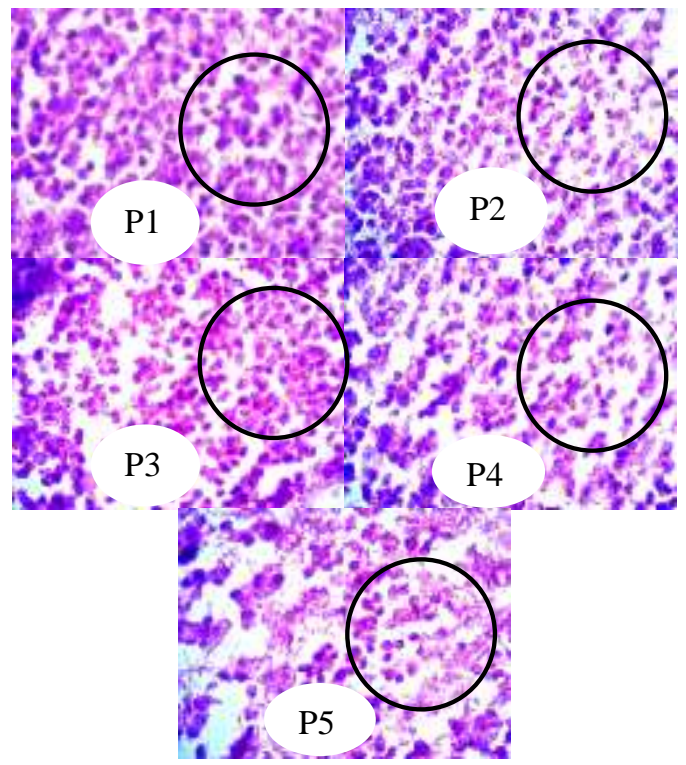

Gambar 1. Sel Pulau Langerhans Pankreas Mencit Jantan Hasil Pewarnaan HE (400x). P1 (Kontrol Positif), P2 (Kontrol Negatif), P3 (Ekstrak Kulit Buah Manggis Dosis $200 \mathrm{mg} / \mathrm{Kg} \quad \mathrm{BB}), \quad \mathrm{P} 4$ (Ekstrak Kulit Buah Manggis Dosis $400 \mathrm{mg} / \mathrm{Kg} \mathrm{BB}$ ) dan P5 (Ekstrak Kulit Buah Mangis Dosis $600 \mathrm{mg} / \mathrm{Kg} \mathrm{BB}$ )

Hasil pengamatan dan perhitungan jumlah sel pulau Langerhans pada pankreas, dapat dilihat pada Tabel 2.

Tabel 2. Rata-rata Sel Pulau Langerhans Pada Pankreas Setelah Perlakuan

\begin{tabular}{|c|c|}
\hline Perlakuan & $\begin{array}{c}\text { Rata-rata Sel Pulau } \\
\text { Langerhans Pankreas }\end{array}$ \\
\hline P1 & $205,6^{\mathrm{a}}$ \\
\hline P2 & $134,0^{\mathrm{b}}$ \\
\hline P3 & $114,2^{\mathrm{b}}$ \\
\hline P4 & $193,0^{\mathrm{a}}$ \\
\hline P5 & $181,8^{\mathrm{a}}$ \\
\hline
\end{tabular}

Berdasarkan Tabel 2 setelah dianalisis data menggunakan uji ANOVA diperoleh $\mathrm{F}$ hitung $<\mathrm{F}$ tabel pada taraf 5\%. F hitung 2.135 sedangkan $\mathrm{F}$ tabel 2,9 pada taraf 5\% 
sehingga tidak dilakukan uji lanjut Duncan.

Pada Tabel 2 diketahui jumlah sel pulau Langerhans berbeda-beda setiap perlakuannya. Pada P1 didapatkan ratarata sel pulau Langerhans tertinggi yaitu berjumlah 205.6 sel sedangkan rata-rata sel pulau Langerhans terendah adalah P3 dengan jumlah 114.2 sel

\section{B. Pembahasan}

Berdasarkan hasil penelitian, diketahui bahwa kadar glukosa darah mencit (Mus musculus L.) jantan mengalami perbedaan setelah diberikan perlakuan. Pada data pertama setelah induksi sukrosa, perlakuan pertama (P1) sebagai kontrol positif yang tidak diberikan perlakuan. Pada perlakuan kedua, ketiga, keempat, dan kelima (P2, P3, P4 dan P5) mencit diinduksi sukrosa selama 5 hari. Kadar glukosa darah mencit jantan tertinggi terdapat pada P2 yaitu 101,4 mg/dL, sedangkan kadar glukosa darah mencit jantan terendah terdapat pada P5 yaitu 83,8 $\mathrm{mg} / \mathrm{dL}$.

Pada P1 rata-rata glukosa darah mencit jantan (Mus musculus L.) yaitu 86 $\mathrm{mg} / \mathrm{dL}$. Pada P2 (kontrol negatif) dan P3 rata-rata glukosa darah mencit jantan yaitu 101,4 mg/dL P2 dan 89 mg/dL P3. Pada $\mathrm{P} 4$ dan $\mathrm{P} 5$ rata-rata kadar gula darah yaitu 91,4 mg/dL P4, dan 83,8 mg/dL P5, terjadi peningkatan kadar gula darah yang cukup tinggi.

Pemberian minuman dan makanan pada mencit kontrol positif tidak memberikan pengaruh terhadap glukosa darah, karena makanan yang diberikan tidak memiliki zat yang dapat meningkatkan kadar glukosa mencit. Apabila Kadar glukosa meningkat setelah makan makanan akan turun kembali sampai setara dengan kadar gukosa darah basal selama proses perpindahan dari kenyang ke lapar (Marks dkk, 2000). Sukrosa yang diberikan menyebabkan terjadinya penyerapan sukrosa oleh tubuh mencit setelah diinduksi sukrosa selama 5 hari (Makalalaq dkk, 2013).
Pengambilan data kedua glukosa darah mencit jantan dilakukan pada hari ke-9 setelah pemberian ekstrak kulit buah manggis (Garcinia mangostana L.) selama 4 hari. Pengukuran kadar gula darah mencit diambil setelah 3 jam pemberian ekstrak kulit buah manggis. Mencit P1 tidak diberikan perlakuan. Mencit P2 yang diinduksi sukrosa tidak diberikan sukrosa kembali setelah 5 hari perlakuan dan tidak diberikan ekstrak kulit buah manggis. Pada P3, P4 dan P5 mencit jantan diberikan ekstrak kulit buah manggis yang dosis berpedoman pada penelitian Fauziah (2013).

Pemberian dosis perlakuan didapatkan berdasarkan dari dosis (Garcinia mangostana L.) yang telah dikonversikan dosis untuk mencit (Mus musculus L.). Ekstrak kulit buah manggis setiap perlakuan memiliki rentang dosis yang sama yaitu $200 \mathrm{mg} / \mathrm{Kg}$ BB mencit. Dosis perlakuan dimulai dari P3 yaitu 200 $\mathrm{mg} / \mathrm{Kg} \mathrm{BB}$, P4 yaitu $400 \mathrm{mg} / \mathrm{Kg} \mathrm{BB}$, dan P5 yaitu $600 \mathrm{mg} / \mathrm{Kg} \mathrm{BB}$.

Kadar glukosa darah mencit tertinggi terdapat pada $\mathrm{P} 2$ yaitu $81,6 \mathrm{mg} / \mathrm{dL}$, sedangkan untuk kadar glukosa terendah terdapat pada P4 yaitu 41,2 mg/dL. Pada P1 dan P2 data rata-rata kadar glukosa darah mencit jantan yaitu mengalami penurunan $\mathrm{P} 1$ sebesar $21,6 \mathrm{mg} / \mathrm{dL}$ dan $\mathrm{P} 2$ sbesar 19,8 mg/dL dari data pertama. Pada P3, P4 dan P5 kadar rata-rata gula darah mencit jantan mengalami penurunan. Penurunan glukosa darah mencit P3 sebesar $11 \mathrm{mg} / \mathrm{dL}, \mathrm{P} 4$ sebesar 50,4 mg/dL, dan P5 sebesar 32,6 mg/dL. 


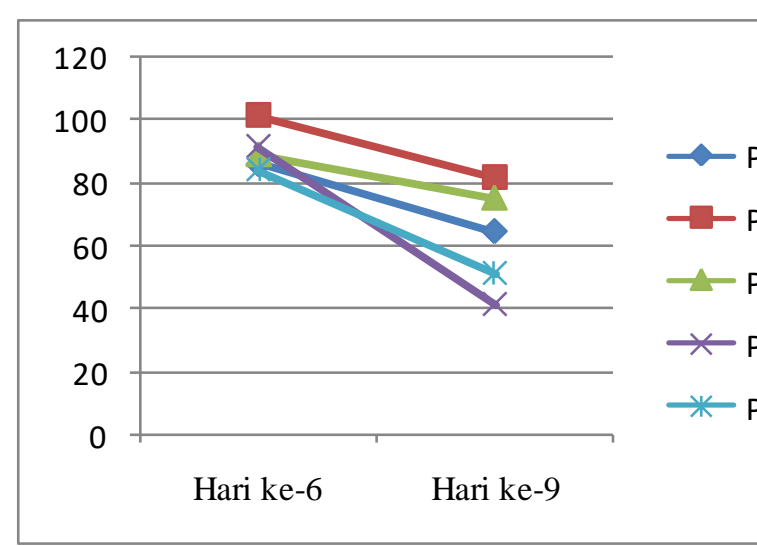

Gambar 2. Pola Perubahan Rata-rata Kadar Glukosa Darah Mencit (Mus musculus L.) Jantan sesudah Induksi Sukosa dan Pemberian Ekstrak Kulit Buah Manggis.

Dilihat dari Gambar 8, Penurunan yang terjadi pada P1 dan P2 dikarenakan mencit tidak diinduksi sukrosa setelah 5 hari. Apabila diinduksi terus menurus akan terjadi peningkatan kadar glukosa darah. Peningkatan kadar glukosa darah terjadi akibat penyerapan glukosa oleh tubuh mencit dikarenakan pengaruh fisiologis tubuh hewan uji (Soriton dkk, 2014). Kadar gula darah pada P3, P4 dan P5 menurun diduga karena adanya kandungan zat aktif flavonoid pada ekstrak kulit buah manggis (Carolus dkk, 2014). Flavonoid merupakan senyawa fenolik alam yang memiliki potensi sebagai antioksidan dan biokaktifasi sebagai obat (Rohyami, 2008). Astuti (2012) menjelaskan flavonoid berfungsi dalam menghambat enzim glukosidase dan alfa amylase sehingga pemecahan karbohidrat menjadi gagal dan glukosa tidak dapat diserap oleh usus. Antioksidan dapat mengikat radikal hidroksil yang merusak sel $\beta$ pulau Langerhans pankreas. Sehingga produksi insulin akan maksimal (Dewi dkk, 2014).

Mekanisme penurunan kadar glukosa darah oleh flavonoid yang dijelaskan Tapas et al., (2008), flavonoid akan meningkatkan sekresi insulin, meningkatkan ambilan glukosa dijaringan perifer dan menghambat glukoneogenesis. Selain iu diketahui dapat mencegah kerusakan sel $\beta$ pankreas karena memliki aktivitas antioksidan dengan cara pmenangkap atau menetralkan radikal bebas terkait dengan gugus $\mathrm{OH}$ fenolik sehingga dapat memperbaiki keadaan $P$ paringan yang rusak (Ayunda, 2014).

Xanton yang merupakan senyawa metabolik kulit buah manggis adalah salah satu flavonoid minor yang memiliki reaksi warna dan gerakan kromatografi serupa dengan flavonoid (Harbone, 1987). Senyawa xanton yang terkandung dalam kulit buah manggis memiliki antioksidan yang tinggi serta bersifat sebagai imunomodulator yang dapat menstabilkan sel-sel di dalam tubuh (Mardiana, 2011). Handayani (2013) menyatakan Imunomodulator merupakan senyawa yang dapat mengembalikan, memperbaiki, dan mempetahankan sistem imun yang fungsinya terganggu atau menekan yang fungsinya berlebihan. Hal ini didukung oleh pendapat Hariyanti dkk (2015) bahwa ekstrak etanol 70\% kulit buah manggis pada dosis 1000,0 memiliki aktivitas sebagai imunomodulator. Hal ini diketahui melalui uji fagositosis pada sel secara in vitro. Mardiana (2011) menyatakan bahwa kelebihan senyawa xanton pada kulit buah manggis dapat meningkatkan sistem kekebalan tubuh, menurunkan tingkat depresi dan menstabilkan fungsi jaringan dalam tubuh.

Hasil pengamatan preparat histologi pankreas mencit (Mus musculus L. Swiss Webter) jantan setelah perlakuan 9 hari menggunakan metode pewarnaan hematoksilin eosin (HE). Gambaran histologi sel pulau Langerhans pada pankreas dari hasil penelitian dengan perbesaran 1000x didapatkan pada P1 rata-rata sel pulau Langerhans yaitu 205.6. Pada P2 yang diinduksi sukrosa rata-rata sel pulau Langerhans yaitu 134 tidak terjadinya perubahan morfologi yaitu kerusakkan sel pulau Langerhas. Induksi 
yang dilakukan menggunakan sukrosa tidak mengakibatkan kerusakkan yang signifikan. Sukrosa hanya meningkatkan glukosa darah pada mencit jantan.

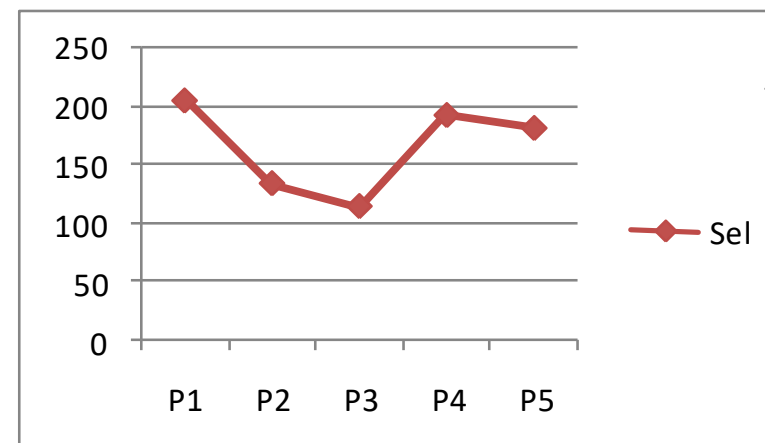

Gambar 9. Pola Perubahan Rata-rata Sel Pulau Langerhans Pada Pankreas Mencit (Mus musculus L.) Jantan Setelah Diberikan Perlakuan.

Berdasarkan Gambar 9, P3, P4 dan P5 yang diberikan ekstrak kulit manggis dengan dosis $200 \mathrm{mg} / \mathrm{Kg} \mathrm{BB}, 400 \mathrm{mg} / \mathrm{Kg}$ $\mathrm{BB}$ dan $600 \mathrm{mg} / \mathrm{Kg}$ BB rata-rata sel pulau Langerhans pada pankreas yaitu P3 114.2, P4 193 dan P5 181.8. menunjukkan adanya kecendrungan perubahan morfologi yang lebih baik, hal ini menggambarkan adanya peningkatan jumlah sel pulau Langerhans lebih banyak.

Pulau Langerhans dalam keadaan normal terlihat dari penyebaran sel-sel endokrin yang teratur menyebar di pulau Langerhans dengan bentuk yang seragam dan inti terlihat jelas (Sholikhatin dkk, 2013). Senyawa flavonoid mempunyai struktur yang ideal sebagai antioksidan yaitu penangkal radikal dengan adanya senyawa fenol lebih dari satu yang tersusun oleh gugus aromatik dan gugus $\mathrm{OH}$ serta adanya ikatan rangkap terkonjugasi dimana struktur tersebut dibutuhan dalam penangkapan radikal pebas (Aulanni'iam dkk. 2012).

Kerusakan sel-sel pankreas dapat disebabkan oleh banyak faktor. Faktor tersebut diantaranya genetik, infeksi oleh kuman, faktor nutrisi, zat diabetogenik, dan radikal bebas (stress oksidatif). Perubahan histopatologi sel pulau Langerhans pada penderitan DM terjadi secara kuantitatif yaitu pengurangan jumlah dan ukuran dan secara kualitatif seperti terjadinya nekrosis, degenerasi dan lain-lain (Suarsana dkk. 2010). Penelitian Hamidatun dkk (2014), perbaikan sel $\beta$ pankreas terkait dengan senyawa bioaktif yang terkandung dalam cuka salak yakni flavonoid yang termasuk golongan senyawa polifenol yang selama ini terbukti memiliki aktivitas antioksidan. Menurut Suryani dkk (2013) aktivitas antioksidan mampu menangkap radikal bebas penyebab kerusakan sel $\beta$ pankreas dan menghambat kerusakan sel beta pankreas sehingga sel $\beta$ yang tersisa masih tetap berfungsi. Antioksidan tersebut diduga mampu melindungi sejumlah sel-sel $\beta$ yang tetap normal sehingga memungkinkan terjadinya regenerasi selsel $\beta$ yang masih ada melalui proses mitosis atau melalui pembentukan pulau baru dengan cara proliferasi dan diferensiasi endokrin. Adanya perbaikan pada sel $\beta$ penghasil insulin, maka terjadi peningkatan jumlah insulin di dalam tubuh yang mampu menfasilitasi masuknya glukosa darah ke dalam sel sehingga terjadi penurunan kadar glukosa darah dalam tubuh.

Penelitian yang telah dilakukan menggunakan sukrosa tidak merusak sel pulau Langerhans pada pankreas hanya saja meningkatkan kadar gula darah. Sukrosa adalah gula yang digunakan setiap harinya yang berasal dari tebu mauun buat bit dan dapat juga dari buah lainnya. Dengan hidrolisis sukrosa akan terpecah dan menghasilkan glukosa dan fruktosa. Pada molekul sukrosa tidak memiliki gugus aldehida atau keton bebas, dan tidak mempunyai gugus $-\mathrm{OH}$ glikosidik. Dengan demikian sukrosa tidak mempunyai sifat yang dapat 
mereduksi ion-ion $\mathrm{Cu}^{++}$atau $\mathrm{Ag}^{+}$dan juga tidak membentuk osazon (Poedjadi, 2006). Tidak seperti Aloksan dan Streptozotocin senyawa yang dapat menyebabkan kerusakan pada sel pulau Langerhans. Senyawa aloksan didalam tubuh mengalami metabolisme oksidasi reduksi menghasilkan radikal bebas dan radikal aloksan sehingga mengakibatkan kerusakan pada se pulau Langerhasn khususnya sel $\beta$ pulau Langerhans pada pankreas (Suarsana dkk, 2010). Induksi senyawa Streptozotocin meningkatkan kapasitas radikal bebas akibat pelepasan radikal nitrogen oksida (NO) sehingga menyebabkan kerusakan sel terutama sel $\beta$ pankreas (Dewi dkk, 2013).

\section{KESIMPULAN DAN SARAN}

\section{A. Kesimpulan}

Dari penelitian ini dapat disimpulkan pemberian ekstrak kulit buah manggis (Garcinia mangostana L.) tidak berpengaruh terhadap histologis pankreas mencit (Mus musculus L.) jantan yang diinduksi sukrosa

\section{B. Saran}

Perlu dilakukan penelitian lanjutan untuk mengetahui dosis ekstrak kulit buah manggis yang tepat untuk

\section{DAFTAR PUSTAKA}

Astuti, V. C. Y. 2012. Pengaruh Pemberian Ekstrak Daun Kumis Kucing (Orthosiphon aristatus) Terhadap Penuruna Kadar Glukosa Darah Tikus Wistar yang Diinduksi Aloksan. Skripsi. Fakultas Kedokteran. Universitas Diponegoro.

Aulanni'am, A. Rosdiana, dan N. L. Rahmah. 2012. The Potency of Sargasum duplicatum Bory Extract on Inflammatory Bowel Disease Therapy in Rattus norvegicus. Journal of Life Sciences. Vol 6: 144-154
E-ISSN : 2549-7464, P-ISSN : 1411-3724

Ayunda. R. 2014. Uji Aktivitas Jamu Gendong Kunyit Asam (Curcuma domestica Val.; Tamarindus indica L.) Sebagai Antidiabetes Pada Tikus yang Diinduksi Streptozotocin. Skripsi. Fakutas Kedokteran. Universitas Tanjungpura Pontianak.

Carolus, F. P., Fatimawali dan D. S. Wewengkang. 2014. "Uji Efektifitas Kulit Batang Jambu Mete (Anacardium Occidentale L.) Terhadap Penurunan Kadar Glukosa Darah Pad Tikus Putih Jantan Galus Wistar (Rattus norvegicus) yang Diinduksi Aloksan". Jurnal ilmiah Farmasi. 3(3): 204-210.

Darmawangsyih. 2014. Khasiat Buah Manggis Untuk Kehidupan. Jurnal Al-Hikmah. 15(1): 60-63.

Dayatri, U. A. 2009. Profil sel $\beta$ Pulau Langerhans Jaringan Pangkreas Tikus Diabetes Mellitus Yang Diberi Virgin Coconut (VCO). Skripsi. Fakultas Kedokteran Hewan. Institut Pertanian Bogor.

Dewi, I. D. A. D. Y., K. W. Astuti dan N. K. Warditiani. 2013. Skrining Fitokimia Ekstrak Eatanol 95\% Kulit Buah Manggis (Garcinia mangostana L.). Jurnal Farmasi Udaya. Bali: Universitas Udayana.

Dewi, Y. F., M. S. Anthara dan A. A. G. O. Dharmayudha. 2014. "Efektivitas Ekstrak Daun Sirih Merah (Piper crocatum) Terhadap Penurunan Kadar Glukosa Darah Tikus Putih jantan (Rattus novergicus) Yang Diinduksi Aloksan". Buletin Veterier Udayana. 6(1): 73-79

Emilan, T. dan Ashfar. 2011. Manggis (Garcinia mangostana). Tugas Mata Kuliah Farmakologi. Universitas Indonesia: Jakarta.

Fauzia, N., R. Sumarmin. dan G. Indriati. 2013. Pengaruh Ekstrak Kulit 
E-ISSN : 2549-7464, P-ISSN : 1411-3724

Buah Manggis

mangostana

L.)

Hematokrit

(Mus musculus L.) Swiss Webster.

Jurnal Skripsi. STKIP PGRI Sumatera Barat.

Fransiska, P. A., D. Winarsono dan S.

Muwarni. 2014. Pengaruh

Pemberian Ekstrak Curcuma

Longa L Terhadap Titer

Interleukin-6 (Il-6) Dan Gambaran

Histologi Pankreas Pada Tikus

(Rattus Norvegicus) Model

Diabetes Melitus Tipe 1. Malang:

Kedokteran Hewan Universitas

Bawijaya.

Ganiswarma, S. G. 1995. Farmakologi dan Terapi.Edisi 4. Jakarta: Gaya Baru Press.

Ganong, W. F. 1995. Buku Ajar Fisiologi Manusia. Jakarta: EGC.

Hamidatun, O. K. Mandasari, I. Rosdiana, S. D. Widiyana. 2014. Pengaruh Cuka Salak Terhadap Penurunan Glukosa Darah dan Histopatolog Pankreas Tikus Diabetes. Fakultas Teknologi Pertanian. Universitas Brawijaya Malang.

Handayani, D., A. Yufri, O. Nisya. 2013. Uji Imunomodulator Beberapa Subfraksi Ekstrak Etil Asetat Meniran (Phyllanthus niruri L.) pada Mencit Putih Jantan dengan Metode Carbon Clearance. Jurnal Farmasi. Padang: Universitas Andalas.

Harbone, J. B. 1987. Metode Fitokimia (Terjemahan). Bandung: ITB.

Hariyanti, S. Hadi, dan N. Sari. 2015. Efek Imunomodulator Fraksi Etanol dari Ekstrak Etanol 70\% Kulit Buah Manggis (Garcinia Mangostana L.) berdasarkan Peningkatan Aktivitas dan Kapasitas Fagositosis Sel Makrofag Peritoneum Mencit secara In Vitro. Journal Pharmacy. 12(1): 58-69.
Nugrahani, S. S. 2012. Ekstrak Akar, Batang, dan Daun Herbal Meniran Dalam Menurunkan Kadar Glukosa Darah. Jurnal Kesehatan Masyarakat 8(1): 51-59.

Makalalag, I. W., A. Wullur dan A. Wiyono. 2013. Uji Ekstrak Daun Binahong (Anredera cordifolia Steen.) terhadap kadar Gula Darah Pada Tikus Putih Jantan Galur Wistar (Rattus norvegicus) yang diinduksi Sukrosa. Jurnal Ilmiah Farmasi Vol. 2 (1): 28-34.

Mardiana, L. 2011. Ramuan dan Khasiat Kulit Buah Manggis. Jakarta: Penebar Swadaya.

Marks, D. B., A. D. Marks, dan C. M. Smith. 2000. Biokimia Kedokteran Dasar. Jakarta: EGC.

Indrajati, V. 2013. Herbal Ahli Atasi Penyakit. Jakarta: Penebar Swadaya.

International Diabetes Federal (IDF). 2014. Data Visualisation (www.idf.org/daibetesatlas/datavisualitation) diakses 04 Oktober 2015.

Pebriyanthi dan N. Erlina. 2010. Ekstraksi Xanthone Dari Kulit Buah Manggis (Gracinia mangostana L.) Dan Aplikasinya Dalam Bentuk Sirup.Abstrak.file:///D:/indeks\%20 glikemik/manggis/62279.htm. diakses 19 September 2015.

Pearce. E. 2002. Anatomi dan Fiologi untuk Paramedis. Jakarta: PT. Gramedia Pustaka utama.

Poedjiadi. A. 2006. Dasar-Dasar Biokimia. Jakarta: UI-Press.

Rohyami, Y. 2008. "Penentuan Kandungan Flavonoid dari Ekstrak methanol Daging Buah Mahkota Dewa (Phaleria macrocarpa Scheff Boerl)". Jurnal Logika. 5(1): 1-8.

Sholikhatin, S., Aulanni'am dan D. K. Wuragil. 2013. Perubahan Kadar Malondialdehid (MDA) dan 
Gambaran Histopatologi Pankreas Pada Tikus (Rattus norvegicus) AITD Hasil Induksi Capra hirus Tiroglobuli (cTg). Jurnal Skripsi. Unversitas Brawijaya.

Soegondo, S., P. Soewondo dan I. Subekti. 2009. Penataklaksanaan Diabetes Mellitus Terpadu. Edisi Kedua. Jakarta: Balai Penerbit FKUI. Hal 3-5.

Suarsana, I. N., B. P. Priosoeryanto, M. Bintang dan T. Wersdiyati. 2010.

Profil Glukosa Darah dan Ultrastruktur Sel Beta Pankreas Tikus yang Diinduksi Senyawa Aloksan. JITV. 15(2): 118-123.

Soriton, H.V. Y., P. V. Yamlean dan W. A. Lolo. 2014. Uji Efektivitas Ekstrak Etanol Daun Tapak Dara (Catharantus roseus (L.) G. Don) terhadap Penurunan Kadar Gula Darah Tikus Putih Jantan Galur Wistar (Rattus norvegicus L.) yang diinduksi Sukrosa. Jurnal Ilmiah Farmasi UNSRAT. Vol. 3(3): 162169.

Suryani, Nany, Endang, Tinny, dan Aulanni`am. 2013. Pengaruh Ekstrak Biji Metanol terhadap Peningkatan Kadar Insulin, Penurunan Ekspresi TNF- $\alpha$ dan Perbaikan Jaringan Pankreas Tikus Diabetes. Jurnal Kedokteran Brawijaya. 27(3).

Tapas, A. R., D. M. Sakarkar dan R. B. Kakde. 2008. Flavonoid as Natraceuticals: A Review. Tropical Journal of Pharmaceutical Research. 7(3): 1089-1099

Utami, P dan Tim lentera. 2004. Tanaman Obat untuk Mengatasi Diabetes Mellitus. Jakarta: PT. Agromedia Pustaka.

Yatman, E. 2012. Kulit Buah Manggs Mengandung Xanton Yang Berhasiat Tinggi.Wawasan. (324). 